\title{
Iniciativas
}

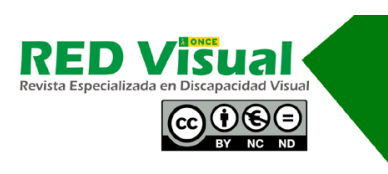

Recepción: 04-03-2021 Aceptación: 23-03-2021

\section{El Heraldo Confinado, el periódico del alumnado de la ONCE en Aragón}

\author{
A. Martín Vega, L. Santos Roig
}

iUna pandemia! ¿Quién podía imaginarse que algo así llegaría de repente a nuestras vidas?

Cuando nos enfrentamos a una situación desconocida, lo más probable es que en nuestro interior surjan sentimientos de incertidumbre, miedo e inquietud, sentimientos que nos revuelven y desequilibran, sentimientos que son difíciles de controlar y organizar para evitar, de esta forma, desestabilizarnos.

La covid-19 tuvo el gran poder de provocar esto mismo a la vez en toda la humanidad. Increíble, ¿no? En la historia más reciente nada había afectado a tantos millones de personas en un mismo momento de forma tan similar. Repentinamente, un virus coarta nuestra libertad, limita los abrazos y los besos, nos obliga a estar encerrados, a hacer uso de la tecnología como único recurso para poder ver y hablar con nuestros seres queridos.

Pero, seguramente, todo esto se acrecentó aún más en las personas con discapacidad visual. ¿Cómo íbamos a acceder a la información si no podíamos tocar con las manos?, ¿si teníamos que guardar una distancia de dos metros?, ¿si sentíamos miedo cuando alguien se nos acercaba demasiado? Incluso cuando nos hablaban... Se presentaba de nuevo un reto para nosotros. Nos encontrábamos ante una situación delicada en la que había que poner en marcha recursos que ayudasen a minimizar los sentimientos y emociones negativas que, probablemente, iban a surgir.

Nuestros alumnos transmitían dicha inquietud ante la desconocida situación y ante la falta de soluciones. Pensamos que nos tocaba actuar, conseguir distraer la mente 
y buscar noticias positivas en un momento en el que los medios de comunicación no retransmitían más que información relacionada con la pandemia. Actuar en estos primeros momentos les ayudaría a mantener la calma, la serenidad y a no sumergirse en un mar de pensamientos negativos. Y es que, como decía la Madre Teresa de Calcuta, «La paz comienza con una sonrisa».

Este fue nuestro objetivo al crear El Heraldo Confinado, un periódico formado por muchos redactores escolares para provocar sonrisas, sonrisas que ayudaran a calmar las mentes, sonrisas con las que evadirnos de la situación que nos envolvía, y también conseguir mantenernos unidos a familias, profesionales y alumnos. Porque no solo era importante que el alumnado no perdiese las relaciones entre ellos, también nosotros necesitábamos sentirnos cerca. Para ello, teníamos un único requisito: solo publicaríamos noticias positivas. Una vez establecido el objetivo, el Equipo de Servicios Sociales de la ONCE en Aragón nos pusimos manos a la obra. Los protagonistas serían los alumnos: se encargarían de enviarnos noticias de ellos mismos y de su entorno más cercano, o, también, noticias que les despertasen un interés especial.

Figura 1. Un proyecto que nos mantiene unidos



Así, los seis números publicados durante el confinamiento se componían de diferentes secciones: entrevistas, música, relatos, actividades complementarias, moda, deportes, literatura, cocina, retos personales, chistes, naturaleza, investigación, etc. iVaya éxito!, pensamos. Recibíamos gran cantidad de vídeos y de imágenes a través de las cuales nos transmitían esos sucesos positivos. La gran participación mostrada 
solo podía significar una cosa: nuestros alumnos estaban deseosos de regalar sus experiencias y artes más personales a todos los demás para crear un espacio de diversión. iQué importante es sentirse protagonista!

Abríamos la recepción de noticias casi a la par que la publicación del número anterior. En ese momento, los redactores - que podían ser cualquiera de los alumnoscomenzaban a preparar el tema y asunto que quisieran compartir. Durante el plazo de una semana quedaba abierta la «redacción del periódico» para recibir las noticias en el formato que se quisiera presentar: escrito, acompañado de fotografías o grabado en vídeo. Una vez recibido el material, procedíamos con el proceso de maquetación, tanto en versión PDF, como en formato web a través de la plataforma WordPress para ser publicado en nuestro blog, Servicios Sociales ONCE Aragón. Finalizada esta laboriosa fase, procedíamos a la distribución de los ejemplares por los cauces del correo electrónico y de la mensajería WhatsApp.

Este proyecto para nosotros significó algo más. Lo que conseguíamos con él era mucho mayor de lo que en un principio esperábamos. Desde diferentes ámbitos (familiar, escolar, etc.) nos trasmitían lo felices que a algunos chicos les estaba haciendo $E I$ Heraldo Confinado. El hecho de contar con la posibilidad semanal o quincenal de tener su propia sección, de ser protagonistas de sus historias y contárselas a los demás, generaba una motivación extra en un momento en el que el confinamiento les impedía realizar aquellas actividades.

Alicia Martín Vega. Maestra del Equipo de Atención Educativa ONCE en Aragón. Paseo Echegaray y Caballero, 76; 50003 Zaragoza (España). Correo electrónico: almag@once.es.

Luis Santos Roig. Maestro del Equipo de Atención Educativa ONCE en Aragón. Paseo Echegaray y Caballero, 76; 50003 Zaragoza (España). Correo electrónico: 1sr@once.es. 